Review

\title{
The challenge of controlling urban mosquito-borne diseases in a changing urban climate
}

\author{
Antonio Ligsay ${ }^{1,2}$, Olivier Telle ${ }^{3}$ \& Richard E. Paul 4,*
}

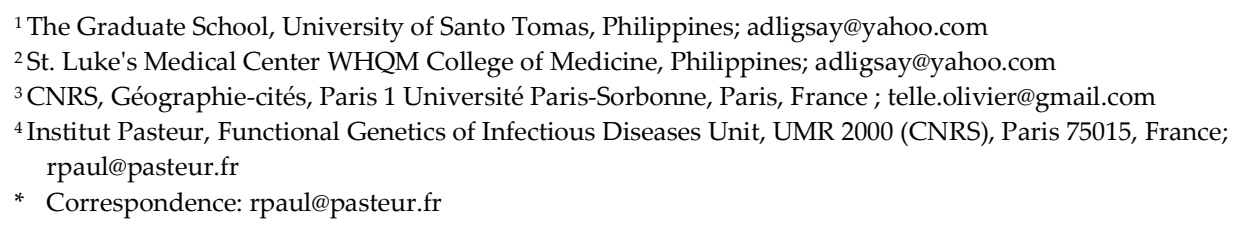

\begin{abstract}
Cities worldwide are facing ever-increasing pressure to develop mitigation strategies for all sectors to deal with the impacts of climate change. Cities are expected to house $70 \%$ of the world's population by 2050 and developing related resilient health systems is a significant challenge. Because of their physical nature, cities' surface temperatures are often substantially higher than that of the surrounding rural areas, generating the socalled Urban Heat Island (UHI) effect. Whilst considerable emphasis has been placed on strategies to mitigate against the UHI-associated negative health effects of heat and pollution, the World Health Organization estimates that one of the main consequences of global warming will be an increased burden of such vector-borne diseases. Many of the major mosquito-borne diseases are urban and thus the global population exposed to these pathogens will steadily increase. Mitigation strategies beneficial for one sector may, however, be detrimental for another. Implementation of inter-sectoral strategies that can benefit many sectors (such as water, labour and health) do exist and would enable optimal use of the meagre resources available. Discussion among inter-sectoral stakeholders should be actively encouraged.
\end{abstract}

Keywords: Climate change; Urban Heat Islands; Mosquito-borne Disease; Mitigation Strategies

\section{Introduction}

Five years on from the landmark Paris agreement in 2015 to reduce global warming to below $2^{\circ} \mathrm{C}$, global carbon dioxide emissions have continued to rise steadily, with a resulting increase in the global average temperature of $1.2^{\circ} \mathrm{C}[1,2]$. With the five hottest years ever recorded coming after 2015, global warming continues to accelerate. Impacts of climate change are omnipresent and can be observed across the different sectors (Agriculture, energy, water supply, coasts, ecosystems, forests, society, transport and health). They are, however, unevenly distributed across the globe, and, consequently, there are large regional differences in exposure, vulnerability, and adaptation to climate change and impacts are disproportionally occurring in countries not responsible for our plight [2]. Climate change is already impacting human health with the burden expected to increase over the coming decades [3]. Managing health risks will require modifying health systems to become more resilient. Such adaptation will be required for decades, with the degree of mitigation being a key determinant of the ability of the health systems to manage risks projected later into the century $[3,4]$. Irrespective of the success of adaptation and mitigation, residual risks from climate change will burden health systems, particularly in low- and middle-income countries. The ensuing costs of managing the health risks of climate variability will be very significant including not only costs associated with increased health care and public health interventions, but also costs associated with the labour sector (lost 
work days and lower productivity) and with maintaining well-being; this latter will be particularly pronounced in the urban setting. As an example, the health costs associated with six climate change-related events that struck the United States between 2000 and 2009 has been estimated to exceed \$14 billion [5]. As much as costs can be estimated, predictions have suggested that they will run into billions of dollars even when only addressing the major causes of morbidity and mortality as regional levels [4]. They also suggest that without climate-resilient development, climate change could force more than 100 million people into extreme poverty by 2030 [6]. Perseverance with a business-as-usual approach to climate change will endanger lives and livelihoods leading to a higher health burden that could have been prevented. While the time scale of climate change is in the order of decades, decision frameworks for public health officials and regional planners need to be based on much shorter time scales [7]. The climate-changerelated threat to public health and the focus of decision makers on much shorter timescales calls for an approach combining both timescales, with both short- and long-term policy recommendations. One of the major factors hindering the development of policy recommendations, especially those concerning health, is that there is no consensus of how the world will develop during this century.

\section{Global warming, climate change and projection scenarios}

In 1988, with recognition of the global warming, the United Nations Environment Programme and the World Meteorological Organization created the Intergovernmental Panel on Climate Change with a mandate to provide policymakers with regular scientific assessments on climate change, its implications and potential future risks, as well as to put forward adaptation and mitigation options [8]. Initial efforts were made in the 1990s to explore future developments in the global environment and were published in the Special Report on Emissions Scenarios [9]. Subsequently, following the many societal changes over the past 20 years, two new initiatives were developed: The Representative Concentration Pathways (RCPs) and the Shared Socioeconomic Pathways (SSPs). The RCPs describe different levels of greenhouse gases and other radiative forcings that might occur in the future. To predict how much warming would be expected to occur four pathways were envisaged. To complement the RCPs and to take into account how socioeconomic factors (including population, economic growth, education, the rate of technological development and especially urbanisation) would change over time and further impact on the climate, the SSPs were developed. The SSPs look at five different scenarios in which the world might evolve in the absence of climate policy (Box 1). Which of these scenarios is most likely to occur will be fundamental to guide short and long-term health policies. This thus represents the major challenge for governments and cause for serious debate. 
Box 1 Shared Socioeconomic Pathways (Adapted from [10])

SSP1: Sustainability - Taking the Green Road (Low challenges to mitigation and adaptation): The world shifts gradually toward a more sustainable path. Management of the earth's shared natural resources improves, educational and health investments accelerate the demographic transition (evolving from high to low birth and infant death rates) and the emphasis on economic growth shifts towards emphasis on well-being. Driven by an increasing commitment to achieving development goals, inequality is reduced internationally. Consumption is oriented toward a less materialistic society and lower resource and energy utilisation.

SSP2: Middle of the Road (Medium challenges to mitigation and adaptation): The world follows a path in which social, economic, and technological trends do not shift from historical patterns. Income inequality within and among countries persists or improves only slowly and challenges to reducing vulnerability to societal and environmental changes remain. Global and national institutions work toward but make slow progress in achieving sustainable development goals. Ecosystems experience degradation but the intensity of resource and energy use declines. Global population growth is moderate.

SSP3 Regional Rivalry - A Rocky Road (High challenges to mitigation and adaptation): Increasing nationalistic views, apprehensions about competitiveness and security, and regional conflicts lead countries to increasingly focus on domestic issues. Policies shift to become increasingly oriented toward national security issues. Countries focus on achieving energy and food security goals locally. Investments in education and technological development decline. Economic development is slow, consumption is material-intensive and inequalities worsen over time. Population growth is low in industrialized and high in developing countries. A low international priority for addressing environmental concerns leads to strong ecosystem degradation.

SSP4 Inequality - A Road Divided (Low challenges to mitigation, high challenges to adaptation):

Highly unequal investments in human capital (economic value of the abilities and qualities of labour that influence productivity, such as education), combined with increasing socio-economic disparities, lead to increasing inequalities internationally. Socio-economic disparities, notably in economy, health and education, increase exacerbating the existing gaps between high- and low-income countries. The globally connected energy sector diversifies, with investments in both carbon-intensive fuels and low-carbon energy sources. Environmental policies focus on local issues in middle- and high- income areas.

SSP5 Fossil-fuelled Development - Taking the Highway (High challenges to mitigation, low challenges to adaptation): This world places increasing faith in competitive markets, innovation and participatory societies to produce rapid technological progress and development of human capital as the path to sustainable development. Global markets are increasingly integrated, with strong investments in health, education, and institutions to enhance human and social capital. Simultaneously, the drive for economic and social development is coupled with the exploitation of abundant fossil fuel resources and the adoption of resource and energy intensive lifestyles leading to rapid growth of the global economy. Despite this, environmental problems such as air pollution are successfully managed. 


\section{Climate change impacts on health}

Climatic changes has devastating impacts on many aspects of health through droughts, floods, storms, coastal flooding, forest fires, agricultural production, natural water sources, landslides, heat waves, proliferation of microbes and spread of arthropod vectors of pathogens [11-15]. Many diseases have climatic niches and their emergent and epidemic dynamics are influenced by variability in the climate [16, 17]. Analyses suggest that low-income countries will bear the brunt of the predicted health impact $[2,18,19]$. Africa and Asia, for example, bear the largest economic burden of disease in humans [20] and are where the influence of climate variability on health is already widely recognized [2123]. Increasing temperatures will inevitably lead to hotter days, more frequent and longer heatwaves leading to an increase in heat-related deaths. In addition to impacting immediate mortality, there will be an increase in heat stroke and dehydration as well as cardiovascular (CVD), respiratory and cerebrovascular disease. The health impact will particularly affect urban areas that are warmer than the surrounding rural areas. Warming will also affect air quality with an increase in ground level ozone. High-levels of ozone cause breathing problems, trigger asthma, reduce lung function and cause lung disease [24]. An increase in particulate matter is also anticipated, not least from an increase in wildfires. This will lead to an increase in Chronic Obstructive Pulmonary Disease and CVD. Finally air quality will worsen will respect to airborne allergens, notably pollen from plants where the season will likely be extended, leading to an increase in allergic diseases, notably asthma and rhino-conjunctivitis. In addition to the evident impact on agriculture in rural areas, $90 \%$ of cities are coastal and thus an increase in extreme weather events, such as floods and storms, will have a disproportionally high impact on the urban environment. Mental health will also decline, an effect particularly felt in urban environments due to the cumulative effects of increased heat. In addition to the negative consequences of global warming for non-infectious diseases, infectious diseases, particularly in an urban setting, are also a cause for concern [25-31]. Global warming will lead to a reduction in water quality and food safety with a proliferation of microbes and an increase in bacterial and viral contamination of water and food.

\section{Climate change and mosquito-borne pathogens}

Many of the most important diseases affecting health are mosquito-borne, including notably malaria and the arboviral diseases (dengue, Zika, Chikungunya). The World Health Organization estimates that one of the main consequences of global warming will be an increased burden of such vector-borne diseases. Climate has a potentially large impact on the incidence of mosquito-borne diseases, directly through the influence of temperature on the developmental rates of both the mosquito and the pathogen within the mosquito, as well as on mosquito survival and indirectly through changes in vegetation and land-surface characteristics, such as the availability of mosquito oviposition sites [32]. Moreover, with increasing global temperatures mosquito-borne pathogens, although currently limited to the tropics and sub-tropics are anticipated to extend their current geographical ranges, invading more temperate regions [33]. Globalisation and increased international travel and trade will enable unwitting importation of mosquito-borne pathogens from endemic areas into formerly disease-free regions, given that infections following infection by many such pathogens can be symptom-free [34-36]. This potential for the spread of mosquito-borne diseases into temperate regions has already occurred with dengue or Chikungunya virus transmission detected sporadically in France [37, 38], Madeira [39], Croatia [40], intermittently in the USA [41, 42].

Several of the mosquito-borne diseases are of particular concern as the mosquito species in question have adapted to the urban environment. This is the case for Aedes aegypti, the vector of dengue, Zika, Chikungunya and Yellow Fever viruses and Anopheles stephensi, the vector of urban malaria (caused by either Plasmodium falciparum or Plasmodium vivax). These pathogens are inflicting a huge health burden globally. More than 3.5 billion people are at risk of dengue virus (DENV) infection in over 100 countries and recent estimates suggest that there are 390 million DENV infections every 
year, of which 100 million cause clinical symptoms [43]. The explosive 2015-16 Zika epidemic infected over a million individuals across 73 countries and the increasing incidence of microcephaly in newborns led the WHO to declare Zika as a public health emergency of international concern [44,45]. That a further 35 countries recorded imported cases underlines the facility with which viruses can be spread globally at a rapid pace. Outbreaks of Chikungunya now occur frequently across the globe in all continents with numbers of cases reaching 100s of thousands [46]. In contrast to the classical Anopheles species mosquito vectors of malaria parasites (for example Anopheles gambiae in sub-saharan Africa and Anopheles dirus in Asia), urban malaria is transmitted by An. stephensi, which like Ae. aegypti has adapted to an urban environment, breeding in water storage containers [47, 48]. Formerly restricted to South East Asia, India and the Arabian peninsula prior to 2011, it has now been reported from Djibouti (2012), Ethiopia (2016), Sri Lanka (2017) and most recently from the Republic of the Sudan (2019) [49-51]. This species is well capable of thriving in an urban environment and is thus threatening to bring an additional malaria burden to that driven by the more rural mosquito vector spp. in a world of ever-increasing urbanization.

The growth of urban populations and the large-scale migration of individuals among locations are among the key defining environmental challenges of the 21st century, especially for human health. Over $50 \%$ of the world's population live in cities and this is expected to increase to approximately $70 \%$ by 2050 [52]. Cities occupy only $3 \%$ of land surface [53] and yet they produce approximately $80 \%$ of gross world product, consume about $78 \%$ of the world's energy and produce more than $60 \%$ of all $\mathrm{CO}_{2}$ emissions [54-56]. The expected dramatic increase in urbanization precludes extrapolation from our current limited understanding of urban health to the future, especially at relevant resolutions taking into account pronounced demographic, socio-economic, environmental and climatic heterogeneity. Socially disadvantaged individuals living in urban settings have been highlighted as a major group at risk for the adverse health consequences of climate change, which will exacerbate the current recognised urban health disparities $[57,58]$. Better quantitative frameworks for guiding regional and urban disease management are thus needed that can take advantage of increasingly detailed geographical, environmental and epidemiological data within cities and for networks of interconnected cities in regions.

Curbing the trajectories of the major urban vector-borne health problems therefore requires consideration of the pronounced spatial and environmental heterogeneity of the urban domain. Urbanization is not only concentrated in the metropolis; small cities and rural areas are also changing fast, but little is known about the mosquito-borne health situation in such areas in highly endemic regions. It is problematical since mobilities of individuals are not only acting as connectors among spaces with different environmental characteristics, but also because mobility clearly drives infectious diseases propagation at city scales $[32,59,60]$. Consequently, viruses can be re-introduced systematically from areas that are not considered central in the governance of diseases.

\section{Urbanization on climate and vice versa}

The most important anthropogenic influences on climate are greenhouse gas emissions and land use change, notably urbanization where vegetation is replaced by man-made surfaces [61-63]. The extensive production of greenhouse gases and urbanization both lead to increases in surface temperatures and can lead to urban heat islands (UHIs), metropolitan areas that are significantly warmer than the surrounding rural areas [64]. Many factors contribute to the creation of UHIs: population density, percent built-up area and density, the reflectivity (albedo) and thermal bulk properties of man-made surfaces, including impervious surfaces (roads, pavements), lack of vegetation areas and water bodies, the thermal mass that is produced by anthropogenic activities (transportation, industry) and urban morphology (high-rise building, variation in the height of building, sky view factor, etc.) [65, 66]. All these features will affect evaporative cooling and convection efficiency transferring heat to the lower atmosphere [67]. Whilst generally 
considered at the city vs. neighbouring rural environment scale, even at small intra-urban scales, the effects of urban geometry, both with the shading effect in daytime and with the reduction of radiative cooling and increasing thermal storage at night, can generate differences in UHI intensity at a very local scale [32, 68]. During the daytime, the UHI intensity is largely influenced by convection efficiency associated with surface roughness and changes in the partitioning of latent or sensible heat fluxes associated with local climate-vegetation characteristics [69, 70]. In addition to the influence of urban structure and geometry on convection efficiency, humidity also has a significant negative effect because of the increased aerodynamic resistance to heat diffusion [67].

The public health impact of UHIs has been directly implicated in exacerbating the negative effects of extreme temperature conditions, air pollution, poorer water quality and general discomfort [71, 72]. A knock-on from these health impacts are associated economic losses because of reduced labour productivity [73]. Therefore, any impacts of global climate change will be amplified by the UHIs. For the top 5\% populated cities, the effects of UHI are estimated to add an additional $1.72{ }^{\circ} \mathrm{C}, 2.08^{\circ} \mathrm{C}$ and $2.35^{\circ} \mathrm{C}$ to the estimated temperature increase due to global climate change in 2015, 2050 and 2100, respectively [56]. An estimated 20\% of these cities could experience a total warming of more than $4^{\circ} \mathrm{C}$ in 2050 and $25 \%$ could warm by more than $7^{\circ} \mathrm{C}$ by 2100.

The negative effects of UHIs have, however, largely been neglected for infectious diseases, particularly those of urban importance with significant consequences for mitigation strategies. There is increasing evidence that temperature modifications can have a large impact on the epidemic potential of dengue [74]. Moreover, there are an increasing number of fine scale studies implicating an increased incidence of dengue and mosquito vector densities with Land Surface Temperature, vegetation indices and vertical city $[66,75,76]$. Thus, for a variety of reasons, urbanization will be associated with increased local temperatures compared to neighbouring rural areas, with resulting impact on the burden of mosquito-borne diseases.

\section{Mitigation strategies for UHIs}

In recognition of the growing and predicted problem of UHIs, a considerable effort has been made to develop mitigation strategies to alleviate the urban climate problem. The most extensive approach has been undertaken by Singapore, which has developed over 80 different strategies [77]. These can be grouped into seven categories: vegetation, urban geometry, water bodies, materials and surfaces, shading, transport, and energy. Strategies based around vegetation have been highlighted as particularly effective, as well as being cost effective and relatively easily and rapidly implemented as compared with the other categories. Hence vegetation has been used extensively as a UHI mitigation strategy worldwide [78-80] in innumerable ways at micro (e.g. vertical gardens, planting trees along transport axes creating green corridors) and mesoscales (e.g. increasing urban parks and encouraging urban agriculture). Planting vegetation reduces the impact of incoming solar energy by shading and because of the relatively high albedo of vegetation also reduces accumulation of heat. The shading effect can not only reduce the sensible heat flux but also the latent heat flux. Green corridors can not only shade via trees, but also the use of grass reduces turbulent vertical air movements produced by hot surfaces, thereby improving convection efficiency. One problem is, however, that in tropical countries with high humidity, vegetation can increase thermal discomfort. In such wet climates, the extent of green coverage necessary to reduce the temperature differential (of the UHIs compared to rural areas) would lead to excessive thermal discomfort. Hence, it has been suggested that under such circumstances increased shading rather than simply increased vegetal mass would be more effective $[69,70]$. By contrast, in drier climates that are water-limited, there is low evapotranspiration and low albedo and thus increased greening is predicted to be more effective [69, 70]. This underlines the point that strategies will not be expected to work the same everywhere. Another problem with excess vegetation is that it impacts upon another health issue: mosquito-borne disease. Inner city parks and green zones 
are known to provide havens for mosquitoes and dengue risk has been shown to increase for people living in dwellings close to such green spaces [59]. This is a key point in developing health mitigation strategies when there are many different health issues to consider. Moreover, mitigation strategies in other sectors may also have an impact on health. Managing water resources is predicted to become a serious problem, especially in the urban setting and inadequate permanent access to water leads to water storage practices that enables proliferation of mosquito populations and increased disease [68]. In this case, strategies to improve water supplies could lead to sectorial co-benefits.

\section{Tackling urban mosquito-borne disease in the face of UHI mitigation}

Mosquito control in urban settings is very challenging, not least because of the complexity of the environment and the multitude of man-made containers that can provide oviposition sites for mosquitoes to lay eggs in [47]. For Ae. aegypti mosquitoes, which are day-time biters, current control approaches focus on source reduction by improved environmental hygiene (eliminating solid waste that offer potential oviposition sites), using larvicides in stored water objects (vases, urns, storage jars, overhead tanks etc) to eliminate the immature stages of the mosquitoes and adulticides to kill adult stages of the mosquito. This latter is generally employed in and around cases of dengue identified through the public health system. Personal protective methods such as window netting and mosquito nets, coils and sprays are used, but whose efficacy is unclear [81]. Source reduction and community-based environmental management have shown some success $[82,83]$, but requires massive efforts and considerable community engagement. The need for novel methods for reducing mosquito densities and human exposure to mosquitoes are desperately required [84]. One of the major challenges for targeting the immature mosquito stages is the inability to find and treat the abundance of potential breeding sites. One new method is to use the adult female mosquitoes themselves to disseminate the insecticide - autodissemination - with the assumption that she will find oviposition sites better than humans [85-89]. Whilst this has been to shown to work, at least in reducing mosquito numbers, the urban geometry has a significant impact on efficacy, for the simple reason that mosquitoes do not fly over high walls and generally will not fly very far [88, 90]. This hampers the dissemination of the insecticide and requires deployment of auto-dissemination devices at unacceptably high densities. Whilst other new control methods are showing promise [91], mitigating against urban vector-borne diseases could use the leverage of other sectors impacted upon by climate change - notably water, environmental/ecosystem hygiene and urban geometry. Lack of piped water has been shown to be a risk factor for dengue and is likely also to be the case for urban malaria [68]. It is also a clear concern for drinking water quality generally. Inter-sectoral co-benefits would thus arise from focussing on access to water. Improved environmental hygiene is crucial for reducing pollutants and maintaining a healthy urban environment. Solid waste matter provides abundant sites for mosquito breeding [92]. Thus again, strategies on environmental hygiene would lead to inter-sectoral co-benefits. Urban housing quality and geometry impact upon the extent of exposure of man to mosquitoes and are clear determinants of heat impacts. With careful discussion, mosquito control methods such as auto-dissemination and use of toxic baited sugar traps [93] could benefit from the creation of green oases that lure mosquitoes to these safe havens and either locally kill the adult mosquitoes or enable the adults to disseminate the insecticide more freely locally along green "ventilation" corridors [94]. Improved access to permanent running water, reduced urban heat stress through improved urban geometry amongst other approaches and a reduced burden of mosquito-borne disease need to be considered through intersectorial collaboration for co-creation of resilient strategies [95, 96].

\section{Conclusion}

Despite the fundamental importance for public health to know the magnitude and patterns of climate impacts and their significance for prioritization and allocation of resources to protect populations, the health research 
community largely work in isolation of the other sectors. However, to ensure sustainable development, it is imperative that public health is included in climate change policies and climate services across sectors. Inter-sectoral collaboration has improved over recent years through the cross-sectorial impact model inter-comparison project - ISIMIP - but health has been, unlike other sectors, only vaguely and sporadically present in this effort [97-99]. Such collaborative intersectoral work now needs to be carried out at the specific level of cities to align with the sustainable development goals of making cities and human settlements inclusive, safe, resilient and sustainable through improvements to housing and basic services [96]. There are a significant number of mitigation strategies that would allow cities to confront the challenges of climate change. Inter-sectoral collaboration would optimise the meagre resources with which cities have to manage the many foreseeable problems that will arise.

Author Contributions: Conceptualization, O.T. and R.E.P.; writing-original draft preparation, A.L., O.T. and R.E.P.; writing-review and editing A.L., O.T. and R.E.P. All authors have read and agreed to the published version of the manuscript.

Funding: This research received no external funding.

Acknowledgments: None declared.

Conflicts of Interest: The authors declare no conflict of interest.

\section{References}

1. COP21 https://www.apc-paris.com/cop-21. (Accessed 9 February 2021).

2. Watts, N.; Amann, M.; Arnell, N.; Ayeb-Karlsson, S.; Beagley, J.; Belesova, K.; Boykoff, M.; Byass, P.; Cai, W.; Campbell-Lendrum, D.; et al. The 2020 report of The Lancet Countdown on health and climate change: responding to converging crises. Lancet 2021, 397, 129-170, doi: 10.1016/S0140-6736(20)32290-X.

3. Smith, K. R.; Woodward, A.; Campbell-Lendrum, D.; Chadee, D. D.; Honda, Y.; Liu, Q.; Olwoch, J.M.; Revich, B.; Sauerborn, R. Human Health: Impacts, Adaptation, and Co-Benefits. In: Climate Change 2014: Impacts, Adaptation, and Vulnerability; Part A: Global and Sectoral Aspects. Contribution of Working Group II to the Fifth Assessment Report of the Intergovernmental Panel on Climate Change; Field, C.B.; Barros, V.R.; Dokken, D.J.; Mach, K.J.; Mastrandrea, M.D.; Bilir, T.E.; Chatterjee, M.; Ebi, K.L.; Estrada, Y.O.; Genova, R.C.; et al. Eds.; Cambridge University Press, Cambridge, United Kingdom and New York, NY, USA, 2014; pp. 709754, ISBN 9781107415379.

4. Ebi, K.L.; Hess, J.J.; Watkiss, P. Health Risks and Costs of Climate Variability and Change. In: Injury Prevention and Environmental Health, 3rd edition; Mock, C.N.; Nugent, R.; Kobusingye, O.; Smith, K.R. Eds.; The International Bank for Reconstruction and Development / The World Bank: Washington (DC), USA, 2017; Available from: https://www.ncbi.nlm.nih.gov/books/NBK525226/ doi: 10.1596/978-1-4648-0522-6_ch8, ISBN: 978-1-46480522-6.

5. Knowlton, K.; Rotkin-Ellman, M.; Geballe, L.; Max, W.; Solomon, G. M. Six climate change-related events in the United States accounted for about \$14 billion in lost lives and health costs. Health Affairs 2011, 30(11), 2167-2176, doi: 10.1377/hlthaff.2011.0229.

6. Hallegatte, S.; Bangalore, M.; Bonzanigo, L.; Fay, M.; Kane, T.; Narloch, U.; Rozenberg, J.; Treguer, D.; VogtSchilb, A. Shock Waves: Managing the Impacts of Climate Change on Poverty. World Bank: Washington DC, USA, 2016; pp. 207, ISBN (electronic) 978-1-4648-0674-2.

7. U.S. Global Change Research Program. The Impacts of Climate Change on Human Health in the United States: A Scientific Assessment. U.S. Global Change Research Program, Washington DC, USA, 2016 ; pp. 312. https://health2016.globalchange.gov/. (Accessed 15 February 2021). 
8. The Intergovernmental Panel on Climate Change. https://www.ipcc.ch/ (Accessed 15 February 2021).

9. IPCC. Special Report on Emissions Scenarios. Nakicenovic, N.; Swart, R. Eds.; Cambridge University Press, UK, 2000; pp. 570, ISBN 0521804930.

10. Riahi, K.; van Vuuren, D.P.; Kriegler, E.; Edmonds, J.; O’Neill, B.C.; Fujimori, S.; Bauer, N.; Calvin, K.; Dellink, R.; Fricko, O; et al. The Shared Socioeconomic Pathways and their energy, land use, and greenhouse gas emissions implications: An overview. Glob. Environ. Change 2017, 42, 153-168, ISSN 0959-3780, doi: 110.1016/j.gloenvcha.2016.05.009.

11. Murray, V.; Ebi, K.L. IPCC Special Report on Managing the Risks of Extreme Events and Disasters to Advance Climate Change Adaptation (SREX). J. Epidemiol. Community Health 2012, 66(9), 759-760, doi: 10.1136/jech-2012201045.

12. McMichael, A.J. Globalization, climate change, and human health. N. Engl. J. Med. 2013, 368, 1335-1343, doi: 10.1056/NEJMra1109341.

13. IPCC. Climate Change 2014: Impacts, Adaptation, and Vulnerability; Part A: Global and Sectoral Aspects. Contribution of Working Group II to the Fifth Assessment Report of the Intergovernmental Panel on Climate Change; Field, C.B.; Barros, V.R.; Dokken, D.J.; Mach, K.J.; Mastrandrea, M.D.; Bilir, T.E.; Chatterjee, M.; Ebi, K.L.; Estrada, Y.O.; Genova, R.C.; et al. Eds.; Cambridge University Press, Cambridge, United Kingdom and New York, NY, USA, 2014; pp. 1132, ISBN 9781107415379.

14. Woodward, A.; Smith, K.R.; Campbell-Lendrum, D.; Chadee, DD.; Honda, Y.; Liu, Q.; Olwoch, J.; Revich, B.; Sauerborn, R.; Chafe, Z.; et al. Climate change and health: on the latest IPCC report. Lancet 2014, 383(9924), 11851189, doi: 10.1016/S0140-6736(14)60576-6.

15. Watts N, Adger WN, Agnolucci P, Blackstock J, Byass P, Cai W, Chaytor, S.; Colbourn, T.; Collins, M.; Cooper, A.; et al. Health and climate change: policy responses to protect public health. Lancet 2015, 386, 1861-1914, doi:10.1016/S0140-6736(15)60854-6.

16. Linthicum, K.J.; Anyamba, A.; Tucker, C.J.; Kelley, P.W.; Myers, M.F.; Peters, C. Climate and satellite indicators to forecast Rift Valley fever epidemics in Kenya. Science 1999, 285, 397-400, doi: 10.1126/science.285.5426.397.

17. Bicout, D.J.; Sabatier, P. Mapping Rift Valley Fever vectors and prevalence using rainfall variations. Vector-Borne Zoonotic Dis. 2004, 4, 33-42, doi: 10.1089/153036604773082979.

18. Friel, S.; Marmot, M.; McMichael, A.; Kjellstrom, T.; Vågerö, D. Global health equity and climate stabilisation need for a common agenda. Lancet 2008, 372, 1677-1683, doi: 10.1016/S0140-6736(08)61692-X.

19. Parry, M.; Arnell, N.; Berry, P.; Dodman, D.; Fankhauser, S.; Hope, C.; Kovats, S.; Nicholls, R.; Satterthwaite, D.; Tiffin, R.; et al. Assessing the Costs of Adaptation to Climate Change: a Review of the UNFCCC and Other Recent Estimates. International Institute for Environment and Development and Grantham Institute for Climate Change London, UK, 2009; ISBN: 978-1-84369-745-9.

20. Sachs, J.; Malaney, P. The economic and social burden of malaria. Nature 2002, 415, 680-685, doi: 10.1038/415680a.

21. Bouma, M.J.; Sondorp, H.E.; van der Kaay, H.J. Health and climate change. Lancet 1994, 343, 302-304, doi: 10.1016/S0140-6736(94)91152-5.

22. Confalonieri, U.; Menne, B.; Akhtar, R.; Ebi, K.L.; Hauengue, M.; Kovats, R.S.; Revich, B.; Alistair Woodward, A. Human health. In: Climate Change 2007: Impacts, Adaptation and Vulnerability. Contribution of Working Group II to the Fourth Assessment Report of the Intergovernmental Panel on Climate Change; Parry, M.L.; Canziani, O.F.; Palutikof, J.P.; van der Linden, P.J.; Hanson, C.E. Eds.; Cambridge University Press, Cambridge, UK, 2007; 391431. 
23. Cash, B.A.; Rodó, X.; Kinter, J.L. Links between tropical Pacific SST and cholera incidence in Bangladesh: role of the western tropical and central extratropical Pacific. J. Climate 2009, 22: 1641-1660, doi: https://doi.org/10.1175/2008jcli2177.1.

24. World Health Organization. Air Quality Guidelines Global Update 2005. Particulate matter, ozone, nitrogen dioxide and sulfur dioxide. WHO, 2005 Update. 2006. https://www.euro.who.int/_data/assets/pdf_file/0005/78638/E90038.pdf (Accessed on 11 February 2021).

25. Luterbacher, J.; Dietrich, D.; Xoplaki, E.; Grosjean, M.; Wanner, H. European seasonal and annual temperature variability, trends, and extremes since 1500. Science 2004, 303, 1499-1503, doi: 10.1126/science.1093877.

26. Barriopedro, D.; Fischer, E.M.; Luterbacher, J.; Trigo, R.M.; García-Herrera, R. The hot summer of 2010: Redrawing the temperature record map of Europe. Science 2011, 332, 220-224, doi: 10.1126/science.1201224.

27. Ballester, J.; Robine, J.-M.; Herrmann, F.R.; Rodo, X. Long-term projections and acclimatization scenarios of temperature-related mortality in Europe. Nat. Commun. 2011, 2, 358, doi: 10.1038/ncomms1360.

28. Semenza, J.C.; Rubin, C.H.; Falter, K.H.; Selanikio, J.D.; Flanders, W.D.; Howe, H.L.; Wilhelm, J.L. Heat-related deaths during the July 1995 heat wave in Chicago. N. Engl. J. Med. 1996, 335, 84-90, doi: 10.1056/NEJM199607113350203.

29. Kaiser, R.; Rubin, C.H.; Henderson, A.K.; Wolfe, M.I.; Kieszak, S.; Parrott, C.L.; Adcock, M. Heat-related death and mental illness during the 1999 Cincinnati heat wave. Am. J. Forensic Med. Pathol. 2001, 22, 303-307, doi: 10.1097/00000433-200109000-00022.

30. Robine, J.-M.; Cheung, S.L.K. ; Le Roy, S.; Van Oyen, H.; Griffiths, C.; Michel. J.-P.; Herrmann, F.R. Death toll exceeded 70,000 in Europe during the summer of 2003. C. R. Biol. 2008, 331, 171-178, doi: 10.1016/j.crvi.2007.12.001.

31. Ostro, B.D.; Roth, L.A.; Green, R.S.; Basu, R. Estimating the mortality effect of the July 2006 California heat wave. Environ. Res. 2009, 109, 614-619, doi: 10.1016/j.envres.2009.03.010.

32. Misslin, R.; Telle, O.; Daudé, E.; Vaguet, A.; Paul, R.E. Urban climate versus global climate change - what makes the difference for dengue? Ann. New York Acad. Sci. 2016, 1382(1): 56-72, doi: 10.1111/nyas.13084.

33. Kraemer, M.U.G.; Reiner, R.C.; Brady, O.J.; Messina, J.P.; Gilbert, M.; Pigott, D.M.; Yi, D.; Johnson, K.; Earl, L.; Laurie B. Marczak, L.B. et al. Past and future spread of the arbovirus vectors Aedes aegypti and Aedes albopictus. Nat. Microbiol. 2019, 4, 854-863, doi: https://doi.org/10.1038/s41564-019-0376-y.

34. Grange, L.; Simon-Loriere, E.; Sakuntabhai, A.; Gresh, L.; Paul, R.; Harris, E. Epidemiological Risk Factors Associated with High Global Frequency of Inapparent Dengue Virus Infections. Front. Immunol. 2014, 5, 280, doi: 10.3389/fimmu.2014.00280.

35. Duong, V.; Lambrechts, L.; Paul, R.E.; Ly, S.; Lay, R.S.; Long, K.C.; Huy, R.; Tarantola, A.; Scott, T.W.; Sakuntabhai, A.; et al. Asymptomatic humans transmit dengue virus to mosquitoes. Proc. Natl. Acad. Sci. U S A 2015, 112, 14688-93, doi: 10.1073/pnas.1508114112.

36. Ly, S.; Fortas, C.; Duong, V.; Benmarhnia, T.; Sakuntabhai, A.; Paul, R.; Huy, R.; Sorn, S.; Nguon, K.; Chan, S.; et al. Asymptomatic Dengue Virus Infections, Cambodia, 2012-2013. Emerg. Infect. Dis. 2019, 25(7),1354-1362, doi: 10.3201/eid2507.181794.

37. La Ruche, G.; Souarès, Y.; Armengaud, A.; Peloux-Petiot, F.; Delaunay, P.; Desprès, P.; Lenglet, A.; Jourdain, F.; Leparc-Goffart, I.; Charlet, F.; et al. First two autochthonous dengue virus infections in metropolitan France, September 2010. Euro Surveill. 2010, 15, 19676, PMID: 20929659. 
38. Grandadam, M.; Caro, V.; Plumet, S.; Thiberge, J.-M.; Souarès, Y.; Failloux, A.-B.; Tolou, H.J.; Budelot, M.; Cosserat, D.; Leparc-Goffart, I.; et al. Chikungunya Virus, Southeastern France. Emerg. Infect. Dis. 2011, 17, 910, doi: 10.3201/eid1705.101873.

39. Sousa, C.A.; Clairouin, M.; Seixas, G.; Viveiros, B.; Novo, M.T.; Silva, A.C.; Escoval, M.T.; Economopoulou, A. Ongoing outbreak of dengue type 1 in the Autonomous Region of Madeira, Portugal: preliminary report. Euro Surveill. 2012, 17, 20333, doi: 10.2807/ese.17.49.20333-en.

40. Gjenero-Margan, I.; Aleraj, B.; Krajcar, D.; Lesnikar, V.; Klobučar, A.; Pem-Novosel, I.; Kurečić-Filipović, S.; Komparak, S.; Martić, R.; Duričić, S.; et al. Autochthonous dengue fever in Croatia, August-September 2010. Euro Surveill. 2011, 16, 19805, PMID: 21392489.

41. Effler, P.V.; Pang, L.; Kitsutani, P.; Vorndam, V.; Nakata, M.; Ayers, T.; Elm, J.; Tom, T.; Reiter, P.; Rigau-Perez, J.G. ; et al. Dengue fever, Hawaii, 2001-2002. Emerg. Infect. Dis. 2005, 11, 742-9, doi: 10.3201/eid1105.041063.

42. Murray, K.O.; Rodriguez, L.F.; Herrington, E.; Kharat, V.; Vasilakis, N.; Walker, C.; Turner, C.; Khuwaja, S.; Arafat, R.; Weaver, S.C.; et al. Identification of dengue fever cases in Houston, Texas, with evidence of autochthonous transmission between 2003 and 2005. Vector Borne Zoonotic Dis. 2013, 13, 835-45, doi: 10.1089/vbz.2013.1413.

43. Bhatt S.; Gething, P.; Brady, O.; Messina, J.P.; Farlow, A.W.; Moyes, C.L.; Drake, J.M.; Brownstein, J.S.; Hoen, A.G.; Sankoh, O.; et al. The global distribution and burden of dengue. Nature 2013, 496, 504-507, doi: 10.1038/nature12060.

44. Paul, R.E. The when and the where of Zika epidemic potential in Europe - an evidence base for public health preparedness. EBioMedicine 2016, 9, 17-18, doi: 10.1016/j.ebiom.2016.06.020.

45. World Health Organization. Zika virus. http://www.who.int/topics/zika/en/. (Accessed February 18, 2021).

46. World Health Organization. Chikungunya virus. https://www.who.int/health-topics/chikungunya\#tab=tab_1 (Accessed February 18, 2021).

47. Kumar, V.; Pande, V.; Srivastava, A.; Gupta, S.K.; Anushrita; Singh, V.P.; Singh, H.; Saxena, R.; Tuli, N.R.; Yadav, N.K.; Paul, R.; Valecha, N.; Telle, O.; Nagpal, B.N. Comparison of Ae. aegypti breeding in localities of different socio-economic groups of Delhi, India. Int. J. Mosq. Res. 2015, 2 (2), 83-88, ISSN Number: $2348-5906$.

48. Thomas, S.; Ravishankaran, S.; Justin, J.A.; Asokan, A.; Mathai, M.T.; Valecha, N.; Thomas, M.B.; Eapen, A. Overhead tank is the potential breeding habitat of Anopheles stephensi in an urban transmission setting of Chennai, India. Malar J 2016, 15(1):274. doi: 10.1186/s12936-016-1321-7.

49. Faulde, M.K.; Rueda, L.M.; Khaireh, B.A. First record of the Asian malaria vector Anopheles stephensi and its possible role in the resurgence of malaria in Djibouti, Horn of Africa. Acta Trop. 2014, 139, 39-43, doi: 10.1016/j.actatropica.2014.06.016.

50. Carter, T.E.; Yared, S.; Gebresilassie, A.; Bonnell, V.; Damodaran, L.; Lopez, K.; Ibrahim, M.; Mohammed, S.; Janies, D. First detection of Anopheles stephensi Liston, 1901 (Diptera: culicidae) in Ethiopia using molecular and morphological approaches. Acta Trop. 2018, 188, 180-186, doi: 10.1016/j.actatropica.2018.09.001.

51. Sinka, M.E.; Pironon, S.; Massey, N.C.; Longbottom, J.; Hemingway, J.; Moyes, C.L.; Willis, K.J. A new malaria vector in Africa: Predicting the expansion range of Anopheles stephensi and identifying the urban populations at risk. Proc. Natl. Acad. Sci. U S A. 2020, 117(40), 24900-24908, doi: 10.1073/pnas.2003976117.

52. https://www.un.org/development/desa/en/news/population/2018-revision-of-world-urbanization-prospects.html, 2018 (Accessed February 4 2021). 
53. Filho, W.L.; Icaza, L.E.; Emanche, V.O.; Al-Amin, A.Q. An Evidence-Based Review of Impacts, Strategies and Tools to Mitigate Urban Heat Islands. Int. J. Environ. Res. Public Health 2017, 14, 1600, doi: 10.3390/ijerph14121600.

54. Stern, N. The Economics of Climate Change: The Stern Review. Cambridge Univ. Press, Cambridge, UK, 2007, pp 712. ISBN: 9780521700801.

55. Dobbs, R.; Smit, S.; Remes, J.; Manyika, J.; Roxburgh, C.; Restrepo, A. Urban World: Mapping the Economic Power of Cities. McKinsey Global Institute, McKinsey and Company 2011. https://www.mckinsey.com/ /media/McKinsey/Featured\%20Insights/Urbanization/Urban\%20world/MGI_urban_world_mapping_economic_power_of_cities_full_report.pdf

56. Estrada, F.; Botzen, W. W. J.; Tol, R. S. J. A global economic assessment of city policies to reduce climate change impacts. Nat. Clim. Change 2017, 7, 403-406, doi:https://doi.org/10.1038/nclimate3301.

57. Global Research Network on Urban Health Equity (GRNUHE). Improving urban health equity through action on the social and environmental determinants of health: final report of The Rockefeller Foundation Global Research Network on Urban Health Equity. University College London and the Rockefeller Foundation, London, UK, 2010.

58. Friel, S.; Hancock, T.; Kjellstrom, T.; McGranahan, G.; Monge, P.; Roy, J. Urban Health Inequities and the Added Pressure of Climate Change: An Action-Oriented Research Agenda. J. Urban Health 2011, 88, 886-895, doi: 10.1007/s11524-011-9607-0.

59. Telle, O.; Vaguet, A.; Yadav, N.K; Lefebvre, B.; Daudé, E.; Cebeillac, A.; Nagpal, B.N.; Paul, R.E. The spread of dengue in an endemic urban milieu - the case of Delhi, India. PLoS One 2016, 11(1), e0146539, doi: 10.1371/journal.pone.0146539.

60. Vikram, K.; Nagpal, B.N.; Pande, V.; Srivastava, A.; Saxena, R.; Anvikar, A.; Das, A.; Singh, H.; Anushrita, Gupta, S.K.; et al. An epidemiological study of Dengue in Delhi, India. Acta Trop. 2016, 153, 21-27. pii: S0001706X(15)30116-9, doi: 10.1016/j.actatropica.2015.09.025.

61. Kalnay, E.; Cai, M. Impact of urbanization and land-use change on climate. Nature 2003, 423, 528-531, doi: https://doi.org/10.1038/nature01675.

62. Zhou, L.; Dickinson, R.E.; Tian, Y.; Fang, J.; Li, Q.; Kaufmann, R.K.; Tucker, C.J.; Myneni, R.B. Evidence for a significant urbanization effect on climate in China. Proc. Natl. Acad. Sci. USA 2004, 101, 9540-9544, doi: 10.1073/pnas.0400357101.

63. Grimm, N.B.; Faeth, S.H.; Golubiewski, N.E.; Redman, C.L.; Wu, J.; Bai, X.; Briggs, J.M. Global Change and the Ecology of Cities. Science 2008, 319, 756-760, doi: 10.1126/science.1150195.

64. Stewart, I.D. A systematic review and scientific critique of methodology in modern urban heat island literature. Int. J. Climatol. 2011, 31, 200-217, doi: https://doi.org/10.1002/joc.2141.

65. Aflaki, A.; Mirnezhad, M.; Ghaffarianhoseini, A.; Ghaffarianhoseini, A.; Omrany, H.; Wang, Z.-H.; Akbari, H. Urban heat island mitigation strategies: A state-of-the-art review on Kuala Lumpur, Singapore and Hong Kong. Cities 2017, 62, 131-145, doi: https://doi.org/10.1016/j.cities.2016.09.003.

66. Nakhapakorn, K.; Sancharoen, W.; Mutchimwong, A.; Jirakajohnkool, S.; Onchang, R.; Rotejanaprasert, C.; Tantrakarnapa, K.; Paul, R. Assessment of Urban Land Surface Temperature and Vertical City Associated with Dengue Incidences. Remote Sens. 2020, 12, 3802, doi: https://doi.org/10.3390/rs12223802.

67. Zhao, L.; Lee, X.; Smith, R. B.; Oleson, K. Strong contributions of local background climate to urban heat islands. Nature 2014, 511, 216-219, doi: https://doi.org/10.1038/nature13462. 
68. Telle, O.; Nikolay, B.; Kumar, V.; Benkimoun, S.; Pal, R.; Nagpal, B.N.; Paul, R.E. Social and environmental risk factors for dengue in Delhi city: A retrospective study. PLoS Negl. Trop. Dis. 2021, 15(2), e0009024, doi: 10.1371/journal.pntd.0009024.

69. Zhou, D.; Zhang, L.; Li, D.; Huang, D.; Zhu, C. Climate-vegetation control on the diurnal and seasonal variations of surface urban heat islands in China. Environ. Res. Lett. 2016, 11, 074009, doi: 10.1088/17489326/11/7/07400.

70. Manoli, G.; Fatichi, S.; Schläpfer, M.; Yu, K.; Crowther, T.W.; Meili, N.; Burlando, P.; Katul, G.G.; Bou-Zeid, E. Magnitude of urban heat islands largely explained by climate and population. Nature 2019, 573, 55-60, doi: https://doi.org/10.1038/s41586-019-1512-9

71. Hajat, S.; Kosatky, T. Heat-related mortality: a review and exploration of heterogeneity. J. Epidemiol. Community Health 2010, 64, 753-760, doi: 10.1136/jech.2009.087999.

72. Lai, L.W.; Cheng, W.L. Urban heat island and air pollution--an emerging role for hospital respiratory admissions in an urban area. J. Environ. Health 2010, 72, 32-35, PMID: 20104832.

73. Zander, K. K.; Botzen, W. J. W.; Oppermann, E.; Kjellstrom, T.; Garnett, S. T. Heat stress causes substantial labour productivity loss in Australia. Nat. Clim. Change 2015, 5, 647-651, doi: 10.1038/nclimate2623.

74. Lowe, R.; Cazelles, B.; Paul, R.; Rodo, X. Quantifying the added value of interannual climate variability in a spatio-temporal dengue model. Stoch. Environ. Res. Risk Assess. 2016, 30, 2067, doi: 10.1007/s00477-015-1053-1.

75. Araujo, R.V.; Albertini, M.R.; Costa-da-Silva, A.L.; Suesdek, L.; Franceschi, N.C.S.; Bastos, N.M.; Katz, G.; Cardoso, V.A.; Castro, B.C.; Capurro, M.L.; et al. São Paulo urban heat islands have a higher incidence of dengue than other urban areas. Braz. J. Infect. Dis. 2015, 19, 146-155, doi: 10.1016/j.bjid.2014.10.004.

76. de Azevedo, T. S.; Bourke, B. P.; Piovezan, R.; Sallum, M. A. M. The influence of urban heat islands and socioeconomic factors on the spatial distribution of Aedes aegypti larval habitats. Geospatial Health 2018, 13(1), doi: https://doi.org/10.4081/gh.2018.623.

77. Acero J.A. Vegetation. In: Strategies for Cooling Singapore: A catalogue of 80+ measures to mitigate urban heat island and improve outdoor thermal comfort. Ruefenacht, L.A.; Acero, J.A. Eds, ETH Zurich Research Collection, Zurich, Switzerland, 2017, doi: https://doi.org/10.3929/ethz-b-000258216.

78. Gunawardena, K. R.; Wells, M. J.; Kershaw, T. Utilising green and bluespace to mitigate urban heat island intensity. Sci. Total Environ. 2017, 584-585, 1040-1055, doi: 10.1016/j.scitotenv.2017.01.158.

79. Akbari, H.; Menon, S.; Rosenfeld, A. Global cooling: increasing world-wide urban albedos to offset CO2. Climatic Change 2009, 94, 275-286, doi: https://doi.org/10.1007/s10584-008-9515-9.

80. Memon, R. A.; Leung, D. Y. C.; Chunho, L. A review on the generation, determination and mitigation of urban heat island. J. Environ. Sci. China 2008, 20, 120-128, doi: 10.1016/s1001-0742(08)60019-4.

81. Bowman, L.R.; Donegan, S.; McCall, P.J. Is Dengue Vector Control Deficient in Effectiveness or Evidence: Systematic Review and Meta-Analysis. PLoS Negl. Trop. Dis. 2016, 10, e0004551, doi: 10.1371/journal.pntd.0004551.

82. Toledo, M.E.; Rodriguez, A.; Valdes, L.; Carrión, R.; Cabrera, G.; Banderas, D.; Ceballos, E.; Domeqc, M.; Peña, C.; Baly, A.; et al. Evidence on impact of community-based environmental management on dengue transmission in Santiago de Cuba. Trop. Med. Int. Health 2011, 16, 744-747, doi: 10.1111/j.1365-3156.2011.02762.x.

83. Nagpal, B.; Gupta, S.K.; Shamim, A.; Vikram, K.; Srivastava, A.; Tuli, N.R.; Saxena, R.; Singh, H.; Singh, V.P.; Bhagat, V.N.; et al. Control of Aedes aegypti Breeding: A Novel Intervention for Prevention and Control of Dengue in an Endemic Zone of Delhi, India. PLoS ONE 2016, 11, e0166768, doi: 10.1371/journal.pone.0166768.

84. Paul, R.; Sousa, C.A.; Sakuntabhai, A.; Devine, G.J. Mosquito control might not bolster imperfect dengue vaccines. Lancet 2014, 384, 1747-8, doi: 10.1016/S0140-6736(14)62071-7. 
85. Devine, G.J.; Perea, E.Z.; Killeen, G.F.; Stancil, J.D.; Clark, S.J.; Morrison, A. Using adult mosquitoes to transfer insecticides to Aedes aegypti larval habitats. Proc. Natl. Acad. Sci. USA 2009, 106, 11530-4, doi: 10.1073/pnas.0901369106.

86. Abad-Franch, F.; Zamora-Perea, E.; Luz, S.L.B. Mosquito-disseminated insecticide for citywide vector control and its potential to block arbovirus epidemics: entomological observations and modeling results from Amazonian Brazil. PLoS Med. 2017, 14, e1002213, doi: 10.1371/journal.pmed.1002213.

87. Overgaard, H.J.; Pientong, C.; Thaewnongiew, K.; Bangs, M.J.; Ekalaksananan, T.; Aromseree, S.; Phanitchat, T.; Phanthanawiboon, S.; Fustec, B.; Corbel, V.; et al. Assessing dengue transmission risk and a vector control intervention using entomological and immunological indices in Thailand: study protocol for a cluster-randomized controlled trial. Trials 2018, 19(1), 122, doi: 10.1186/s13063-018-2490-1.

88. Seixas, G.; Paul, R.; Pires, P.; Alves, G.; De Jesus, A.; Silva, A.C.; Devine, G.; Sousa, C.A. Evaluation of efficacy of auto-dissemination in European field trials. Parasites E Vectors 2019, 12(1), 202, doi: 10.1186/s13071-0193454-3.

89. Salazar, F.; Angeles, J.; Sy, A.K.; Inobaya, M.T.; Aguila, A.; Toner, T.; Bangs, M.J.; Thomsen, E.; Paul, R.E. Efficacy of the In2Care ${ }^{\circledR}$ auto-dissemination device for reducing dengue transmission: study protocol for a parallel two-armed cluster randomised trial in the Philippines. Trials 2019, 20, 269, doi: 10.1186/s13063-019-3376-6.

90. Reiter, P. Oviposition, dispersal, and survival in Aedes aegypti: implications for the efficacy of control strategies. Vector Borne Zoonotic Dis. 2007, 7, 261-73, doi: 10.1089/vbz.2006.0630.

91. O'Neill, SL. The Use of Wolbachia by the World Mosquito Program to Interrupt Transmission of Aedes aegypti Transmitted Viruses. Adv. Exp. Med. Biol. 2018, 1062, 355-360, doi: 10.1007/978-981-10-8727-1_24.

92. Romeo-Aznar, V.; Paul, R.; Telle, O.; Pascual, M. Mosquito-borne transmission in urban landscapes: the missing link between vector abundance and human density. Proc. Biol. Sci. 2018, 285(1884), pii: 20180826, doi: 10.1098/rspb.2018.0826.

93. Achee, N. L.; Grieco, J.P.; Vatandoost, H.; Seixas, G.; Pinto, J.; Ching-Ng, L.; Martins, A.J.; Juntarajumnong, W.; Corbel, V.; Gouagna, C.; et al. Alternative strategies for mosquito-borne arbovirus control. PLoS Negl. Trop. Dis. 2019, 13(1): e0006822, doi: 10.1371/journal.pntd.0006822.

94. Hsieh, C.-M.; Huang, H.-C. Mitigating urban heat islands: A method to identify potential wind corridor for cooling and ventilation. Comput. Environ. Urban Syst. 2016, 57, 130-143, doi: 10.1016/j.compenvurbsys.2016.02.005.

95. Devine, G.J.; Overgaard, H.J.; Paul, R.E. Global Vector Control Guidelines - The Need For Co-Creation. Trends Parasitol. 2019, 35(4), 267-270, doi: 10.1016/j.pt.2018.12.003.

96. Lindsay, S.W.; Wilson, A.; Golding, N.; Scott, T.W.; Takken, W. Improving the built environment in urban areas to control Aedes aegypti-borne diseases. Bull. World Health Organ 2017, 95, 607-608, doi: 10.2471/BLT.16.189688

97. ISIMIP. https://www.isimip.org/ (Accessed February 15 2021).

98. Caminade, C.; Kovats, S.; Rocklov, J.; Tompkins, A.M.; Morse, A.P.; Colón-González, F.J.; Stenlund, H.; Martens, P.; Lloyd, S.J. Impact of climate change on global malaria distribution. Proc. Natl. Acad. Sci. USA 2014, 111(9), 3286-91, doi: 10.1073/pnas.1302089111.

99. Warszawski, L.; Frieler, K.; Huber, V.; Piontek, F.; Serdeczny, O.; Schewe, J. The Inter-Sectoral Impact Model Intercomparison Project (ISI-MIP): Project framework. Proc. Natl. Acad. Sci. USA 2014, 111(9), 3228-32, doi: 10.1073/pnas.1312330110. 